\title{
Multi-objective optimization of methionine+cysteine levels in diets for growing pigs
}

\author{
Nivel óptimo multiobjetivo de metionina+cisteína en dietas para cerdos en crecimiento \\ Otimização multiobjetivo do nível de metionina+cisteína em dietas para suínos em crescimento
}

\author{
José L. Figueroa-Velasco $^{1}$ iD; José A. Martínez-Aispuro ${ }^{1 *}$ iD; María T. Sánchez-Torres ${ }^{1}$ iD; Humberto Vaquera-Huerta ${ }^{2}$ iD; \\ José L. Cordero-Moral ${ }^{1}$; ; Rafael Nieto-Aquino ${ }^{3}$ iD.
}

\begin{abstract}
${ }^{1}$ Programa de Ganadería, Campus Montecillo, Colegio de Postgraduados, Montecillo, Texcoco, Estado de México.
${ }^{2}$ Programa de Estadística, Campus Montecillo, Colegio de Postgraduados, Montecillo, Texcoco, Estado de México.

${ }^{3}$ Tecnológico Nacional de México. Instituto Tecnológico de Huejutla. Ingeniería en Agronomía con especialidad en Zootecnia. Huejutla de Reyes. Hidalgo, México.
\end{abstract}

To cite this article:

Figueroa-Velasco JL, Martínez-Aispuro JA, Sánchez-Torres MT, Vaquera-Huerta H, Cordero-Mora JL, Nieto-Aquino R. Multiobjective optimization of methionine+cysteine levels in diets for growing pigs. Rev Colom Cienc Pecu 2020; 33(4): 228-238. DOI: https://doi.org/10.17533/udea.rccp.v33n4a03

\begin{abstract}
Background: The addition of synthetic methionine to growing pig diets should consider the requirements of the methionine+cysteine complex, as most cysteine is obtained through dietary methionine. Objective: To determine an optimal level of methionine + cysteine $($ Met + Cys) in growing pig diets. Methods: Ninety-nine hybrid (Yorkshire $\times$ Landrace $\times$ Duroc) barrows were used in a completely randomized design (initial body weight: $25.90 \pm 3.99 \mathrm{~kg})$. Nine levels of Met $+\mathrm{Cys}(0.500$, $0.525,0.550,0.575,0.600,0.625,0.650,0.675$, and $0.700 \%$ ) were evaluated during 35 days. To determine a multi-objective optimal level of Met+Cys, growth performance and strongly related carcass traits were evaluated. Results: Average daily feed intake (ADFI) and feed:gain ratio (FGR) showed a linear response to the dietary Met + Cys level ( $<<0.05)$, with estimated optimal concentration at $0.700 \%$. Average daily gain (ADG) did not show any effect on the Met + Cys level ( $p>0.05$ ). Carcass characteristics were not affected by the Met+Cys concentration ( $p>0.05)$. The multi-objective optimal level for ADG, ADFI, and FGR was $0.667 \%$ Met+Cys. Conclusions: According to our results, $0.667 \% \mathrm{Met}+\mathrm{Cys}$ is the best concentration in diets for growing pigs.
\end{abstract}

Keywords: carcass characteristics; cysteine; growth performance; methionine; nutritional requirements; protein; pigs; sulfur amino acids; swine nutrition.

Received: October 11, 2018; accepted: April 14, 2020

*Corresponding autor. km 36.5 Montecillo, Texcoco, Estado de México. C.P. 56230. México. Tel.: 5959520200.

E-mail: alfredo_aispuro@yahoo.com 


\section{Resumen}

Antecedentes: Las dietas para cerdos en crecimiento deben adicionarse con metionina sintética para suplir los requerimientos del complejo metionina + cisteína (Met + Cis), pues ellos producen gran parte de la cisteína que requieren a partir de la metionina dietaría. Objetivo: determinar el nivel óptimo multiobjetivo de Met+Cis en dietas para cerdos en crecimiento. Métodos: noventa y nueve machos castrados híbridos (Yorkshire $\times$ Landrace $\times$ Duroc) se utilizaron en un diseño completamente al azar

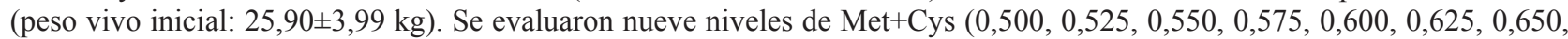
0,675 y $0,700 \%$ ) durante $35 \mathrm{~d}$. Para determinar el nivel óptimo multiobjetivo de Met + Cis se consideraron las variables de rendimiento de crecimiento y características de la canal que mantienen una fuerte interrelación. Resultados: el promedio de consumo de alimento diario (ADFI) y la conversión alimenticia (FGR) mostraron una respuesta lineal al nivel de Met+Cis en la dieta $(p<0,05)$, con una concentración óptima estimada en $0,700 \%$. El nivel de $\mathrm{Met}+\mathrm{Cis}$ no afecto a la ganancia diaria de peso (ADG; $p>0,05)$. La concentración de Met + Cis tampoco afectó las características de la canal $(p>0,05)$. El nivel óptimo multiobjetivo de Met+Cis para ADFI, FGR y ADG fue $0,667 \%$. Conclusión: los resultados indican que $0,667 \%$ de Met + Cis es la mejor concentración en la dieta para cerdos en crecimiento.

Palabras clave: aminoácidos azufrados; características de la canal; cerdos; cisteína; comportamiento productivo; metionina; nutrición de cerdos; proteína; requerimientos nutricionales.

\section{Resumo}

Antecedentes: a adição de metionina em dietas para suínos em crescimento deve ser feita para atender às exigências do complexo metionina + cisteína (Met + Cis), porque grande parte da cisteína é obtida através da dieta com metionina. Objetivo: determinar o nível multiobjetivo ótimo de Met+Cis em dietas para suínos em crescimento. Métodos: noventa e nove suínos machos castrados híbridos (Yorkshire $\times$ Landrace $\times$ Duroc) foram utilizados em delineamento inteiramente casualizado, com peso inicial de 25,90 $\pm 3,99 \mathrm{~kg}$. Nove níveis de Met+Cis $(0,500,0,525,0,550,0,575,0,600,0,625,0,650,0,675$ y $0,700 \%)$ foram avaliados em suínos em crescimento por $35 \mathrm{~d}$. Para determinar o nível multiobjetivo ótimo de Met + Cis, foram consideradas as variáveis de comportamento de crescimento e características do canal que mantêm uma forte inter-relação. Resultados: a ingestão média diária de alimentos (ADFI) e a conversão alimentar (FGR) mostraram uma resposta linear ao nível de Met+Cis na dieta $(\mathrm{p}<0,05)$, estimando a concentração ótima em $0,700 \%$. O ganho de peso diário (ADG) não mostrou efeito devido ao nível de Met+Cis na dieta $(\mathrm{p}>0,05)$. As características da carcaça não foram afetadas pela concentração de Met+Cis na dieta ( $p>0,05$ ). Com ADFI, FGR e ADG, o nível ótimo de Met+Cis foi obtido, encontrando este nível em $0,667 \%$. Conclusões: os resultados indicam que $0,667 \%$ de Met+Cis é a melhor concentração na dieta para suínos em crescimento.

Palavras-chave: aminoácidos sulfurados; características de carcaça; cisteina; comportamento produtivo; exigências nutricionais; metionina; nutrição suína; porcos; proteína. 


\section{Introduction}

Methionine (Met) is the second or third most limiting amino acid (AA) in conventional diets for growing pigs (NRC, 1998; Chen et al., 2014). This sulfur-containing AA plays a role in methylation processes, intestinal oxidative status, maintenance of intestinal mucosal growth and gut function, and is involved in the biosynthesis of creatine, epinephrine, carnitine, taurine, lecithin, choline, melatonin (BauchartThevret et al., 2009; Tesseraud et al., 2009) and cysteine (NRC, 2012). Therefore, a Met deficiency could reduce its availability for protein synthesis and limit animal growth.

Cysteine (Cys) is included in the structure of many proteins, linking polypeptide chains as a precursor of taurine and glutathione (Baker, 1991). Most Cys must be obtained from dietary Met since many feed ingredients lack of adequate Cys levels (Santos et al., 2011). Thus, Met should be added into pig diets to meet the methionine+cysteine (Met+Cys) complex requirement. If the Met level in the diet is insufficient, Cys requirements may not be fulfilled.

According to some reports, low dietary Met+Cys levels improve or have no effect on the productive performance and carcass characteristics of pigs (Santos et al., 2011; Ying et al., 2015. Methionine deficient diets could enhance adipose tissue lipid metabolism, decrease oxidative damage, alter antioxidant pathways, and alleviate the inflammatory responses in growing pigs (Ying et al., 2015; Zhou et al., 2016). Therefore, low levels of Met + Cys could improve growth performance (Santos et al., 2011; Ying et al., 2015; Zhou et al., 2016). Nevertheless, Conde-Aguilera et al. (2010, 2014) observed that reduced Met+Cys levels in pig diets increased fat deposition, reduced protein synthesis and affected carcass characteristics, while Met supplementation seems to improve productive performance (Opapeju et al., 2012; Chen et al., 2014; de Oliveira et al., 2015) when the sulfur-containing
$\mathrm{AA}$ requirements are met, in addition to producing extra benefits from Met acting as a functional AA (Wu et al., 2013). Nevertheless, an excess of Met+Cys can also affect growth performance and carcass characteristics (Santos et al., 2007; Pena et al., 2008).

The appropriate dietary concentration of Met + Cys has not been established because the optimal level of AA depends on the characteristic to be optimized (Zhang et al., 2013). Therefore, the objective of this study was to determine a multi-objective optimal level of Met+Cys in growing pig diets regarding growth performance and carcass characteristics.

\section{Materials and Methods}

\section{Ethical considerations}

The experimental procedures followed the recommendations of the Council for International Organizations of Medical Sciences (CIOMS, 2012) and followed the standards for ethics, biosafety and animal well-being of the Official Mexican Standard (Norma Oficial Mexicana; NOM-062-ZOO, 1999) for the use of experimental animals.

\section{Location}

The experiment was conducted in the Swine Unit at the Experimental Farm of Colegio de Postgraduados, located in Montecillo, State of Mexico ( $98^{\circ} 48^{\prime} 27^{\prime \prime} \mathrm{W}$ and $\left.19^{\circ} 48^{\prime} 23^{\prime \prime} \mathrm{N}\right)$. The climate is temperate, semi-arid, with $15.9^{\circ} \mathrm{C}$ average annual temperature, infrequent frosts, $686 \mathrm{~mm}$ average annual rainfall, and 2,250 $\mathrm{m}$ of altitude (García, 1988).

\section{Animals and experimental design}

Ninety-nine (Yorkshire $\times$ Landrace $\times$ Duroc) hybrid growing barrows were used in a completely randomized design, with $25.90 \pm 3.99$ $\mathrm{kg}$ average body weight (BWi). Nine Met+Cys levels $(0.500,0.525,0.550,0.575,0.600,0.625$, $0.650,0.675$, and $0.700 \%)$ were evaluated during 35 days. These levels were obtained by adding synthetic methionine to the control diet. 


\section{Diets and animal handling}

Diets were formulated based on sorghum-soybean meal, supplemented with crystalline amino acids, and formulated with digestible amino acids (NRC, 2012) to meet or exceed the nu- tritional requirements for this stage of growth (Table 1). Pigs were individually housed in $1.2 \times 1.5 \mathrm{~m}$ pens with concrete floors, equipped with a single feeder and a nipple drinker. Feed and water were provided ad libitum.

Table 1. Composition of experimental diets for growing pigs $(25-50 \mathrm{~kg})$ fed different Methionine + Cysteine levels.

\begin{tabular}{|c|c|c|c|c|c|c|c|c|c|}
\hline & T1 & $\mathbf{T 2}$ & T3 & T4 & T5 & T6 & T7 & T8 & T9 \\
\hline \multicolumn{10}{|l|}{ Ingredient, \% } \\
\hline Sorghum grain & 77.27 & 77.25 & 77.23 & 77.21 & 77.19 & 77.17 & 77.14 & 77.12 & 77.10 \\
\hline Soybean meal & 18.65 & 18.66 & 18.66 & 18.66 & 18.66 & 18.67 & 18.67 & 18.67 & 18.68 \\
\hline Soybean oil & 1.13 & 1.12 & 1.11 & 1.10 & 1.10 & 1.09 & 1.08 & 1.07 & 1.06 \\
\hline Biolys * & 0.74 & 0.74 & 0.74 & 0.73 & 0.73 & 0.73 & 0.73 & 0.73 & 0.73 \\
\hline DL-Methionine & 0.09 & 0.11 & 0.14 & 0.16 & 0.19 & 0.21 & 0.24 & 0.26 & 0.29 \\
\hline L-Threonine & 0.10 & 0.10 & 0.10 & 0.10 & 0.10 & 0.10 & 0.10 & 0.10 & 0.10 \\
\hline Vitamins $* *$ & 0.20 & 0.20 & 0.20 & 0.20 & 0.20 & 0.20 & 0.20 & 0.20 & 0.20 \\
\hline Minerals $* * *$ & 0.15 & 0.15 & 0.15 & 0.15 & 0.15 & 0.15 & 0.15 & 0.15 & 0.15 \\
\hline Common salt & 0.30 & 0.30 & 0.30 & 0.30 & 0.30 & 0.30 & 0.30 & 0.30 & 0.30 \\
\hline Calcium carbonate & 0.56 & 0.56 & 0.56 & 0.56 & 0.56 & 0.56 & 0.56 & 0.56 & 0.56 \\
\hline Orthophosphate & 0.82 & 0.82 & 0.82 & 0.82 & 0.82 & 0.82 & 0.82 & 0.82 & 0.82 \\
\hline Phytase & 0.01 & 0.01 & 0.01 & 0.01 & 0.01 & 0.01 & 0.01 & 0.01 & 0.01 \\
\hline \multicolumn{10}{|c|}{ Estimated content $(\%)$} \\
\hline Metabolizable Energy (Mcal kg-1) & 3.30 & 3.30 & 3.30 & 3.30 & 3.30 & 3.30 & 3.30 & 3.30 & 3.30 \\
\hline Crude protein & 16.79 & 16.81 & 16.82 & 16.83 & 16.85 & 16.86 & 16.88 & 16.89 & 16.90 \\
\hline Lysine & 1.00 & 1.00 & 1.00 & 1.00 & 1.00 & 1.00 & 1.00 & 1.00 & 1.00 \\
\hline Methionine & 0.31 & 0.34 & 0.36 & 0.39 & 0.41 & 0.44 & 0.46 & 0.49 & 0.51 \\
\hline Met+Cys & 0.500 & 0.525 & 0.550 & 0.575 & 0.600 & 0.625 & 0.650 & 0.675 & 0.700 \\
\hline Threonine & 0.60 & 0.60 & 0.60 & 0.60 & 0.60 & 0.60 & 0.60 & 0.60 & 0.60 \\
\hline Tryptophan & 0.17 & 0.17 & 0.17 & 0.17 & 0.17 & 0.17 & 0.17 & 0.17 & 0.17 \\
\hline Phenialanine & 0.73 & 0.73 & 0.73 & 0.73 & 0.73 & 0.73 & 0.73 & 0.73 & 0.73 \\
\hline Arginine & 0.86 & 0.86 & 0.86 & 0.87 & 0.87 & 0.87 & 0.87 & 0.87 & 0.87 \\
\hline Histidine & 0.36 & 0.36 & 0.36 & 0.36 & 0.36 & 0.36 & 0.36 & 0.36 & 0.36 \\
\hline Isoleucine & 0.61 & 0.61 & 0.61 & 0.61 & 0.61 & 0.61 & 0.61 & 0.61 & 0.61 \\
\hline Leucine & 1.45 & 1.45 & 1.45 & 1.45 & 1.45 & 1.45 & 1.45 & 1.45 & 1.45 \\
\hline Valine & 0.76 & 0.76 & 0.76 & 0.76 & 0.76 & 0.76 & 0.76 & 0.76 & 0.76 \\
\hline Calcium & 0.67 & 0.67 & 0.67 & 0.67 & 0.67 & 0.67 & 0.67 & 0.67 & 0.67 \\
\hline Phosphorus & 0.50 & 0.50 & 0.50 & 0.50 & 0.50 & 0.50 & 0.50 & 0.50 & 0.50 \\
\hline
\end{tabular}

T, Treatment. *Biolys, 50.7\%; lysine. **Supplied by kg of feed: 5.0×106 IU vitamin A; $1.0 \times 106$ IU vitamin D3; $2.0 \times 104$ IU vitamin $\mathrm{E} ; 2 \mathrm{~g}$ vitamin $\mathrm{K} 3$; $1 \mathrm{~g}$ thiamine; $5 \mathrm{~g}$ riboflavin; $2 \mathrm{~g}$ pyridoxine; $25 \mathrm{~g}$ niacin; $15 \mathrm{~g}$ D-calcium pantothenate; $3 \mathrm{~g}$ folic acid; $225 \mathrm{~g}$ choline chloride; $0.3 \mathrm{~g}$ antioxidant; $15 \mathrm{mg}$ vitamin $\mathrm{B} 12 ; 180 \mathrm{mg}$ vitamin H-biotin (REKA® Lapisa Animal Nutrition). $* * *$ Supplied by kg of feed: $0.2 \mathrm{~g} \mathrm{Se} ; 0.1 \mathrm{~g} \mathrm{Co} ; 0.3 \mathrm{~g} \mathrm{I} ; 10 \mathrm{~g} \mathrm{Cu} ; 100 \mathrm{~g} \mathrm{Zn} ; 100 \mathrm{~g} \mathrm{Fe} ; 100 \mathrm{~g}$ Mn (REKA® Lapisa Animal Nutrition). 


\section{Variables measured}

The following variables were analyzed: Average daily gain (ADG), average daily feed intake (ADFI), and feed: gain ratio (FGR). On the first and last days of experimentation, backfat thickness (BT) and longissimus muscle area (LMA) were measured using a realtime ultrasound Sonovet 600 with a $3.5 \mathrm{MHz}$ transducer (Medison, Inc., Cypress, California, USA). These data, along with the initial and final body weights, were used to determine the fat-free lean gain (FFLG) and the lean meat percentage (LMP) using the NPPC (Burson and Berg, 2001) equation.

\section{Statistical analysis}

The animals were assigned to one of the nine treatments, using a completely randomized design with nine Met + Cys levels. Each pig was considered an experimental unit. The Shapiro-Wilk and Levene's tests were used to check for normal distribution and variance homogeneity assumptions for the analysis of variance. Analysis of variance was performed with the GLM procedure (MINITAB, 2007) to estimate regression coefficients, which included linear and/or quadratic effects, using the $p$-value $(\mathrm{p} \leq 0.05)$, and the coefficient of determination $\left(\mathrm{R}^{2}\right)$ as criteria to determine the best model. Initial body weight (BWi) was used as a covariate.

To obtain the optimal concentrations of Met, a response surface model was built using the RSREG command (MINITAB, 2007), with an optimization technique based on factorial planning to obtain the Met + Cys levels for the different productive and carcass characteristics. Then, maximization of ADG, ADFI, and minimization of FGR were considered to achieve the optimal multi-objective level of the variables affected by the Met+Cys level in the diet. The regression model was adjusted for each variable using the adjusted treatments means by BWi. Subsequently, the Response Optimizer was used to identify the combined configuration values of the input variables to optimize the overall response and determine the individual and composite desirability of the multiple response system (MINITAB, 2007).

\section{Results}

Growth performance variables are presented in Table 2. The ADFI and FGR showed a linear response to the Met+Cys levels in the diet $(p<0.05)$. The optimal concentration of Met + Cys was estimated at $0.500 \%$ to maximize ADFI, and $0.700 \%$ to minimize ADFI (ADFI $=1.68$ $1.01 *$ Met + Cys $\left.+0.032 * B W i ; R^{2}=0.45\right)$. The optimal concentration of Met + Cys to minimize FGR was $0.700 \%\left(\mathrm{FGR}=1.94-0.27^{*}\right.$ Met+Cys $\left.+0.05^{*} \mathrm{BWi} ; \mathrm{R}^{2}=0.41\right)$. The ADG did not show any effect $(p>0.05)$ of the dietary level of Met + Cys. However, to determine the optimum biological level of Met+Cys with multi-objective optimization we thought necessary to consider that ADG showed a quadratic tendency $(\mathrm{p}=0.14)$ because ADG has an important interrelationship with ADFI and FGR, besides, it improves the adjustment of the model. The optimum biological level of Met+Cys that optimized the multi-objective solution was $0.677 \%$. The FFLG, LMP, BT, and LMA were not affected $(\mathrm{p}>0.05)$ by the dietary concentration of Met + Cys.

\section{Discussion}

Methionine requirements can be altered by the protein level of the diet, feeding system, growth potential of the animals, interrelationships with other limiting amino acids, health status of the animal (Rakhshandeh et al.,2014) and interaction with other sulfur-containing amino acids such as cysteine since part of the supplemented Met is converted to Cys (NRC, 2012). Thus, the addition of Met into diets is an alternative to meet the requirements of the Met $+\mathrm{Cys}$ complex. Digestible Met + Cys requirements were established based on a minimum of $50 \%$ of sulfur-containing amino acids being supplied by Met (Rostagno et al., 2011).

There is no agreement on the digestible Met+Cys requirements of pigs. In the present experiment, we found that the optimal level of Met+Cys for ADFI and FGR was $0.70 \%$; however, when considering the multi- 
Table 2. Treatment means for the productive performance of growing pigs fed with different levels of methionine+cysteine (Met+Cys).

\begin{tabular}{|c|c|c|c|c|c|c|c|c|c|}
\hline Met+Cys (\%) & $\begin{array}{c}\text { ADFI } \\
\left(\mathrm{kg} \mathrm{d}^{-1}\right)\end{array}$ & $\begin{array}{c}\text { ADG } \\
\left(\mathrm{kg} \mathrm{d}^{-1}\right)\end{array}$ & FGR & $\begin{array}{l}\text { BWi } \\
(\mathrm{kg})\end{array}$ & $\begin{array}{c}\text { BWf } \\
(\mathrm{kg})\end{array}$ & $\begin{array}{c}\text { FFLG } \\
\left(\mathrm{kg} \mathrm{d}^{-1}\right)\end{array}$ & $\begin{array}{c}\text { LMP } \\
(\%)\end{array}$ & $\begin{array}{c}\text { BT } \\
(\mathrm{mm})\end{array}$ & $\begin{array}{l}\text { LMA } \\
\left(\mathrm{cm}^{2}\right)\end{array}$ \\
\hline 0.500 & 1.82 & 0.74 & 2.46 & 28.28 & 51.89 & 0.28 & 30.09 & 7.71 & 21.35 \\
\hline 0.525 & 1.68 & 0.75 & 2.25 & 27.80 & 52.28 & 0.27 & 29.44 & 7.25 & 20.15 \\
\hline 0.550 & 1.72 & 0.80 & 2.17 & 23.05 & 53.88 & 0.30 & 29.23 & 8.16 & 20.69 \\
\hline 0.575 & 1.81 & 0.75 & 2.40 & 27.73 & 52.33 & 0.27 & 29.37 & 7.50 & 19.97 \\
\hline 0.600 & 1.83 & 0.77 & 2.45 & 24.13 & 53.01 & 0.30 & 29.61 & 8.28 & 21.51 \\
\hline 0.625 & 1.84 & 0.79 & 2.32 & 28.63 & 53.72 & 0.29 & 29.92 & 8.04 & 21.69 \\
\hline 0.650 & 1.54 & 0.76 & 2.04 & 23.43 & 52.63 & 0.28 & 29.47 & 7.94 & 21.04 \\
\hline 0.675 & 1.63 & 0.72 & 2.25 & 26.91 & 51.32 & 0.29 & 30.16 & 9.27 & 22.43 \\
\hline 0.700 & 1.54 & 0.75 & 2.06 & 23.64 & 52.09 & 0.27 & 29.41 & 7.55 & 20.12 \\
\hline SEM & 0.07 & 0.03 & 0.09 & 1.41 & 1.20 & 0.02 & 0.41 & 0.42 & 0.84 \\
\hline Effect & & & & & p-value & & & & \\
\hline Linear & 0.001 & 0.74 & 0.001 & - & 0.74 & 0.99 & 0.90 & 0.73 & 0.63 \\
\hline Quadratic & 0.01 & 0.14 & 0.16 & - & 0.18 & 0.16 & 0.71 & 0.31 & 0.46 \\
\hline & $\mathrm{R}^{2}$ & & & & & & & & \\
\hline Linear & 0.45 & 0.03 & 0.41 & - & 0.04 & 0.04 & 0.09 & 0.10 & 0.23 \\
\hline Quadratic & 0.48 & 0.04 & 0.42 & - & 0.01 & 0.06 & 0.08 & 0.11 & 0.23 \\
\hline
\end{tabular}

ADFI, average daily feed intake; ADG, average daily gain; FGR, feed:gain ratio; BWi, initial body weight; BWf, final body weight; FFLG, fat-free lean gain; LMP, lean meat percentage; BT, backfat thickness; LMA, longissimus muscle area; SEM, standard error of the mean.

objective optimal level, it was $0.677 \%$. At this concentration, the best FGR is obtained with a lower ADFI, without affecting ADG. According to the NRC $(1998,2012)$, the requirements for digestible Met+Cys for growing pigs (20 $50 \mathrm{~kg}$ ) are estimated to be 0.47 and $0.55 \%$, respectively, whereas the Brazilian tables (Rostagno et al., 2017) have established their requirements based on productive performance (standard and high production) at 0.566 and $0.631 \%$, respectively.

The optimal Met+Cys requirement in our study was higher than that recommended by the NRC $(1998,2012)$, and very close to the one determined by Rostagno et al. (2017). A higher level could lead to extra benefits in the productive performance of the animal. Oral supplementation of Met at 0.02, 0.04, and $0.06 \%$ in growing pigs $(20 \mathrm{~kg})$, improves daily gain, feed intake, and feed: gain ratio, regardless of whether or not there was a deficiency
(Opapeju et al., 2012). Other studies evaluating various dietary Met levels have shown better feed conversion and daily protein deposition in pigs as Met concentrations increase (de Oliveira et al., 2015). It is also reported that an extra $0.12 \%$ of Met supplementation increased ADG and improved feed efficiency during post-weaning (Chen et al., 2014). All these benefits are probably due to the functional role of dietary Met for intestinal growth and function, in addition to its role as a precursor for protein synthesis (Wu et al., 2013).

Our study confirms that reduction of Met + Cys in growing pig diets affects productive variables, as protein synthesis and accretion are affected by insufficient Met levels. CondeAguilera et al. (2010) found that pigs fed a Met deficient diet had lower body weight gain than pigs fed a control diet. Similarly, Kiefer et al. (2005) observed that productive performance and carcass characteristics had a 
quadratic effect in response to the Met+Cys levels $(0.44-0.61 \%)$ in the diets for growing pigs, with the best level between 0.527 and $0.551 \%$. Met and Cys deficiency have been observed to significantly suppress intestinal mucosal growth, reduced intestinal epithelial cell proliferation, and increased intestinal oxidative stress in piglets (Bauchart-Thevret et al., 2009; Chen et al., 2014). Methionine deficiency alters lipid metabolism, decreases oxidative damage, alters antioxidant pathways, and alleviates inflammatory responses in growing pigs (Ying et al., 2015; Zhou et al., 2016). Lower Met+Cys levels in pig diets, compared with NRC (1998) requirements, increase lipid content in subcutaneous adipose tissue and Longissimus dorsi muscle (CondeAguilera et al., 2014; Castellano et al., 2015). Pigs fed a Met deficient diet have a higher lipid composition than pigs fed a basal diet (Batterham et al., 1993; Martinez-Ramirez et al., 2008; Conde-Aguilera et al., 2014). In addition, pigs fed a Met-restricted diet had increased triglyceride content in subcutaneous adipose tissue with unchanged plasma triglyceride contents (Castellano et al., 2015).

Theoretically, a Met deficiency could affect the amounts of Cys and glutathione, consequently increasing oxidative stress, causing damage to the synthesis of important cellular components (fat, protein, DNA; Metayer et al., 2008). Oxidative stress may result in poor performance, disturbed health, and even death (Zheng et al., 2013). When pigs show a stressed-activated immune system, Met requirements are higher since Cys synthesis from Met tends to increase (Li et al., 2014; de Oliveira et al., 2015). A recent study (Conde-Aguilera et al., 2016) suggests that insufficient intake of sulfur AA during early growth may reduce glutathione content in the muscle of growing pigs. Moreover, Met supplementation $(0.12 \%)$ is required for optimal protein synthesis, so, it could increase cysteine and glutathione concentrations in the plasma and tissues, leading to reductions in plasma and tissue redox potential and the maintenance of mucosal integrity in the small intestine of weaned piglets (Chen et al., 2014).
Some studies have shown that excess of Met+Cys can affect growth performance, carcass weight, amount of meat, backfat thickness and daily meat deposition in finishing pigs (Santos et al., 2007; Pena et al., 2008). Recent studies reported that dietary Met restriction in pig diets improved or did not influence growth performance and carcass characteristics (Santos et al., 2011; Ying et al., 2015). In contrast, Caldara et al. (2003) did not find differences in productive variables when using 0.63 to $0.74 \%$ Met+Cys. In addition, Castellano et al. (2015) observed that a dietary Met deficiency resulted in increased lipid content in subcutaneous adipose tissue and Longissimus dorsi muscle, which was associated with an increase in enzyme activity and expression levels of critical genes involved in de novo lipogenesis in these tissues. The activity of antioxidant enzymes increased in adipose and muscle tissues and altered the cellular redox status of young pigs fed a Metdeficient diet. Total antioxidant capacity in the plasma and glutathione levels in the liver were lower in pigs fed Met-deficient diets. These authors (Castellano et al., 2015) concluded that tissue metabolism adapts differently when facing an insufficient supply of dietary Met.

In conclusion, the optimal level of Met+Cys is $0.677 \%$ in growing pig diets to obtain the best feed:gain ratio, average daily gain, and daily feed intake. Our results indicate that below $0.667 \%$ Met + Cys daily feed intake increases to compensate for the lower intake of Met+Cys.

\section{Declarations}

\section{Funding}

Economic support to conduct this research was obtained from "Colegio de Postgraduados".

\section{Conflicts of interest}

The authors declare they have no conflicts of interest with regard to the work presented in this report. 


\section{Author contribution}

José L. Figueroa-Velasco participated in the experimental design, supervision of experimental protocol and wrote the manuscript. José A. Martínez-Aispuro did the experimental work, laboratory analysis, statistical analysis of data and wrote the manuscript. María T. Sánchez-Torres-Esqueda designed and supervised the research and revised final manuscript. Humberto VaqueraHuerta revised the research proposal, statistical analysis and final manuscript. Jose L. CorderoMora collaborated with the proposal set, experimental work, supervised health status of pigs, obtained samples and data from pigs and revised the final version of the manuscript. Rafael Nieto-Aquino collaborated with data collection, revised the research proposal and the final manuscript.

\section{References}

Baker DH. Partitioning of nutrients for growth and other metabolic functions: efficiency and priority considerations. Poult Sci 1991; 70(8):1797-1805. DOI: https://doi.org/10.3382/ps.0701797

Batterham ES, Andersen LM, Baigent DR. Utilization of ileal digestible amino acids by growing pigs: methionine. Br J Nutr 1993; 70(3):711-720. DOI: https://doi.org/10.1079/BJN19930166

Bauchart-Thevret C, Stoll B, Chacko S, Burrin DG. Sulfur amino acid deficiency upregulates intestinal methionine cycle activity and suppresses epithelial growth in neonatal pigs. Am J Physiol Endocrinol Metab 2009; 296(6):1239-1250. DOI: https://doi.org/10.1152/ajpendo.91021.2008

Burson D, Berg E. Procedures for estimating pork carcass composition. Pork quality facts. Des Moines, IA, USA: National Pork Producers Council; 2001.

Caldara FR, Berto DA, Bisinoto KS, da Trindade Neto MA, Wechsler FS. Exigências em metionina de leitões de 6 a $11 \mathrm{~kg}$ com base no conceito da proteína ideal. Acta Sci Anim Sci 2003; 25(1):129-135. DOI: https://doi.org/10.4025/actascianimsci. v25i1.2131

Castellano R, Perruchot MH, Conde-Aguilera JA, Van Milgen J, Collin A, Tesseraud S, Mercier Y, Gondret F. A methionine deficient diet enhances adipose tissue lipid metabolism and alters anti-oxidant pathways in young growing pigs. Plos One 2015; 10(7):e0130514. DOI: https://doi.org/10.1371/journal.pone.0130514

Chen Y, Li D, Dai Z, Piao X, Wu Z, Wang B, Zhu Y, Zeng Z. L-methionine supplementation maintains the integrity and barrier function of the small-intestinal mucosa in post-weaning piglets. Amino Acids 2014; 46(4):1131-1142. DOI: https://doi.org/10.1007/s00726-014-1675-5

CIOMS (Council for International Organizations of Medical Sciences). International Guiding Principles for Biomedical Research Involving Animals. Geneva, Switzerland: CIOMS; 2012.

Conde-Aguilera JA, Barea R, Le Floc'h $\mathrm{N}$, Lefaucheur L, Van Milgen J. A sulfur amino acid deficiency changes the amino acid composition of body protein in piglets. Anim 2010; 4(8):1349-1358. DOI: https://doi.org/10.1017/S1751731110000340

Conde-Aguilera JA, Cobo-Ortega C, Mercier Y, Tesseraud S, Van Milgen J. The amino acid composition of tissue protein is affected by the total sulfur amino acid supply in growing pigs. Anim 2014; 8(3):401-409. DOI: https://doi.org/10.1017/S1751731113002425

Conde-Aguilera JA, Lefaucheur L, Tesseraud S, Mercier Y, Le Floc'h N, van Milgen J. Skeletal muscles respond differently when piglets are offered a diet $30 \%$ deficient in total sulfur amino acid for 10 days. Eur J Nutr 2016; 55(1):117-126. DOI: https://doi.org/10.1007/s00394-014-0830-9

de Oliveira Silva FC, Pinheiro RW, Fontes DO, Scottá BA, Almeida M, Souza LPO, Vidal TZ. Níveis de metionina+cistina para leitões dos 
6 aos $16 \mathrm{~kg}$ submetidos a diferentes graus de ativação do sistema imune. Rev Bras Saúde Prod Anim 2015; 16(4):827-838. DOI: http:// dx.doi.org/10.1590/S1519-99402015000400007

García E. Modificaciones al sistema de clasificación de Köppen (para adaptarlas a las condiciones de la República Mexicana). 4ta ed. México, DF: Universidad Nacional Autónoma de México, Instituto de Geografía; 1988.

Kiefer C, Ferreira AS, Donzele JL, Oliveira RFM, Silva FCO, Brustolini PC. Exigência de metionina+cistina digestíveis para suínos machos castrados mantidos em ambiente termoneutro dos 30 aos $60 \mathrm{~kg}$. R Bras Zootec 2005; 34(3):847-854. DOI: http://dx.doi. org/10.1590/S1516-35982005000300016

Li H, Wan H, Mercier Y, Zhang X, Wu C, Wu X, Wu X, Tang L, Che L. Lin Y, Xu S, Tian G, Wu D, Fang Z. Changes in plasma amino acid profiles, growth performance and intestinal antioxidant capacity of piglets following increased consumption of methionine as its hydroxy analogue. Br J Nutr 2014; 112(6):855-867. DOI: https://doi.org/10.1017/S000711451400172X

Martinez-Ramirez HR, Jeaurond EA, de Lange CF. Dynamics of body protein deposition and changes in body composition after sudden changes in amino acid intake: I. Barrows. J Anim Sci 2008; 86(9):2156-2167. DOI: https://doi.org/10.2527/jas.2007-0235

Metayer S, Seiliez I, Collin A, Duchene S, Mercier Y, Geraert PA, Tesseraud S. Mechanisms through which sulfur amino acids control protein metabolism and oxidative status. J Nutr Biochem 2008; 19(4):207-215. DOI: https://doi.org/10.1016/j.jnutbio.2007.05.006

MINITAB. MINITAB statistical software. V15. PA, USA; 2007.

Norma Oficial Mexicana (NOM-062ZOO-1999). Especificaciones técnicas para la producción, cuidado y uso de animales de laboratorio. Ochoa M. L. I. México, DF: Diario Oficial de la Federación; 2001.
NRC (National Research Council). Nutrient requirements of swine. 10th ed. Washington, DC, USA: National Academy Press; 1998.

NRC (National Research Council). Nutrient requirements of swine. 11th ed. Washington, DC, USA: National Academy Press; 2012.

Opapeju FO, Htoo JK, Dapoza C, Nyachoti CM. Bioavailability of methionine hydroxy analog-calcium salt relative to DL-methionine to support nitrogen retention and growth in starter pigs. Anim 2012; 6(11):1750-1756. DOI: https://doi.org/10.1017/S1751731112000869

Pena SM, Lopes DC, Rostagno HS, de Oliveira Silva FC, Donzele JL. Relações metionina mais cistina digestível:lisina digestível em dietas suplementadas com ractopamina para suínos em terminação. R Bras Zootec 2008; 37(11):1978-1983. DOI: http://dx.doi. org/10.1590/S1516-35982008001100012

Rakhshandeh A, Htoo JK, Karrow N, Miller SP, de Lange CF. Impact of immune system stimulation on the ileal nutrient digestibility and utilisation of methionine plus cysteine intake for whole-body protein deposition in growing pigs. Br J Nutr 2014; 111(1):101-110. DOI: https://doi.org/10.1017/S0007114513001955

Rostagno HS, Albino LFT, Donzeme JL, Gomez PC, Oliveira RF, Lopez DC, Ferreira AS, Barreto SLT, Euclides RF. Brazilian Tables for Poultry and Swine. Composition of feedstuffs and nutritional requirements. 3rd ed. Viçosa, Minas Gerais, Brasil: Universidade Federal de Vicosa- Departamento de Zootecnia; 2011.

Rostagno HS, Albino LFT, Hannas MI, Donzele JL, Sakomura NK, Perazzo FG, Saraiva A, Abreu MLT, Rodriguez PB, Oliveira RF, Barreto SLT, Brito CO. Brazilian Tables for Poultry and Swine. Composition of feedstuffs and nutritional requirements. 4th ed. Viçosa, Minas Gerais, Brasil: Universidade Federal de Vicosa- Departamento de Zootecnia; 2017.

Santos FDA, Donzele JL, Oliveira RFMD, Silva FCDO, Abreu MLTD, Saraiva A, 
Brustolini PCU. Exigência de metionina + cistina digestíveis em suínos machos castrados de alto potencial genético na fase dos 60 aos $95 \mathrm{~kg}$. R Bras Zootec 2007; 36(6):2047-2053. DOI: http://dx.doi.org/10.1590/S1516$\underline{35982007000900014}$

Santos FA, Donzele JL, Oliveira FCS, Oliveira RFM, Abreu MLT, Saraiva A, Haese D, Kill JL. Levels of digestible methionine+cystine in diets for high genetic potential barrows from 95 to 125 kg. R Bras Zootec 2011; 40(3):581-586. DOI: http://dx.doi.org/10.1590/S $1516-$ $\underline{35982011000300016}$

Tesseraud S, Coustard SM, Collin A, Seiliez I. Role of sulfur amino acid in controlling nutrient metabolism and cell functions: implication for nutrition.BrJNutr2009; 101(8):1132-1139. DOI: https://doi.org/10.1017/S0007114508159025

Wu G, Wu ZL, Dai ZL, Yang Y, Wang W, Liu C, Wang B, Wang J, Yin Y. Dietary requirements of nutritionally nonessential amino acids by animals and humans. Amino Acids 2013; 44(4):1107-1113. DOI: https://doi.org/10.1007/s00726-012-1444-2
Ying Y, Yun J, Guoyao W, Kaiji S, Zhaolai D, Zhenlong W. Dietary L-methionine restriction decreases oxidative stress in porcine liver mitochondria.ExpGerontol2015;65:35-41.DOI: https://doi.org/10.1016/j.exger.2015.03.004

Zhang GJ, Xie CY, Thacker PA, Htoo JK, Qiao SY. Estimation of the ideal ratio of standardized ileal digestible threonine to lysine for growing pigs $(22-50 \mathrm{~kg})$ fed low crude protein diets supplemented with crystalline amino acids. Anim Feed Sci Technol 2013; 180(4):83-91. DOI: https://doi.org/10.1016/j.anifeedsci.2013.01.006

Zheng P, Yu B, He J, Tian G, Luo Y, Mao $\mathrm{X}$, Zhang $\mathrm{K}$, Che L, Chen D. Protective effects of dietary arginine supplementation against oxidative stress in weaned piglets. Br J Nutr 2013; 109(12):2253-2560. DOI: https://doi.org/10.1017/S0007114512004321

Zhou X, He L, Wan D, Yang H, Yao K, Wu $\mathrm{G}, \mathrm{Wu} \mathrm{X}$, Yin Y. Methionine restriction on lipid metabolism and its possible mechanisms. Amino Acids 2016; 48(7):1533-1540. DOI: https://doi.org/10.1007/s00726-016-2247-7 